\title{
Development of media education in Canada: a brief history
}

\author{
Hanna Tsvietkova ${ }^{1}$, Olena Beskorsa $^{2,}$, and Liudmyla Pryimenko $^{3}$ \\ ${ }^{1}$ National Pedagogical Dragomanov University, Department for Pedagogy and Psychology of Preschool Education and Children's \\ Creativity, Kyiv, 01601, Ukraine \\ ${ }^{2}$ Donbas State Pedagogical University, Department of Primary Education Theory and Practice, Sloviansk, 84100, Ukraine \\ ${ }^{3}$ Donbas State Pedagogical University, Department of Pedagogy of Higher School, Sloviansk, 84100, Ukraine
}

\begin{abstract}
The article focuses on a holistic retrospective analysis of the history of media education in Canada, which has been done for the first time. Based on the theoretical findings of Canadian media educators, the authors substantiate the periodization, identify the trends, the periodization criteria and three main periods of establishment and development of Canadian media education in the context of sociopolitical and socio-pedagogical determinants. The historical preconditions of the development of media education in Canada are revealed. The essence of media education is regarded as a theory study and development of practical skills for mastering modern mass media, which is considered as part of a specific, autonomous field of knowledge in pedagogical theory and practice. The authors determine that media education is associated with all types of media, which include the set of information and communication tools that each person interacts with in everyday life: printed (newspapers, magazines), auditive (radio, audio) and screen or audiovisual media (cinema, TV, video, multimedia, Internet, etc.); they identify the essential characteristics of media education, determine that media education is the form of media literacy and media culture of an individual; as well as they find out, characterize and systematize the gaps in media education in Canada. The article presents the evolution of media education programs, techniques as well as media education associations. In the context of studying the experience of Canadian media theorists and practitioners, the necessity of applying positive Canadian experience to solve the problems of implementing media education in Ukraine in terms of reforming and humanizing its educational space has been substantiated.
\end{abstract}

\section{Introduction}

Media culture is an integral part of modern informational educational environment. The modern world is full of different media, which greatly affects the lives of people. Speaking of the media, we mean the whole set of information and communication tools which each person uses in everyday life. The field of modern media functioning includes printed means (newspapers, magazines), audio means (radio, sound recordings) and screen or audio-visual means (cinema, TV, video, multimedia, Internet, etc.). The world of a modern person, which is less and less in contact with reality, being surrounded by its representative images as well as images produced by human thinking with the help of the media, is forming under the influence of these information and communication means. So today we can say that the environment that surrounds a person, and the processes in it become largely virtual. Due to the fact that rather large experience has accumulated in the field of information and communication technologies, it allows to implement journalistic, promotional, advertising and artistic functions of the media, the main task of the development of personality is the exploitation of the language sphere, the language culture of new media, with the help of which it becomes possible to provide a competent interaction with society.

Having signed the Bologna Declaration, Ukraine has joined the process of harmonizing the higher education system of many European countries, aimed at ensuring its high quality. The implementation of the Bologna Process and new educational standards is the subject of lively discussion in the domestic scientific community. In particular, to realize such a large-scale integration project, the native higher educational institutions should modernize the educational process. In terms of the world and European educational community, the introduction of media education is an important requirement for the training of specialists in higher educational institutions. This is due to the fact that in order to protect the audience from manipulating the media, modern people need to have special knowledge, communicative and informative skills and abilities, and the capacity of critique (i.e. media literacy) that can be formed through organized and purposeful media education.

Moreover, the methodological recommendations of the Canadian Degree Qualifications Framework are based on the need to develop new competences of different levels, new personal qualities whose absence is detrimental to the comfortable and productive existence

\footnotetext{
* Corresponding author: beskorsyhelen $@$ gmail.com
} 
of a person in the information environment. The development of a well-cultured person, his information competence and literacy became relevant to society.

In this regard, the development of university students' professional competence involves both the use of media education technologies in traditional education and the fundamental restructuring of the entire system, the restructuring of the structure and organization of the educational process, the implementation of appropriate methodological and didactic principles, and the development of pedagogically innovative, media educational and information training technologies.

Consequently, due to the discrepancy between the content and forms of education and the present stage of society development, researchers and educators around the world are searching for a new model of today's higher education institution, effective methods of training aimed at overcoming monotonous learning, which would allow to increase the students' cognitive activity on the basis of their own initiatives when using theoretical knowledge and practical skills.

The implementation of media education as a serious and important area is associated with the majority of the social structures in a democratic society and has been used around the world for over sixty years, particularly in countries such as Canada, Australia, the United States and the United Kingdom. According to the Human Development Index (2013) conducted by UN experts, Canada ranks the first in the world in terms of living standards, the second in terms of the area. Canada is one of the leading countries in the world in terms of the number of computers connected to the Internet, with the help of which the media education process in the country is conducted. The investment in the Canadian education is at a high level (7.1-7.9\% of GDP in 2010-2013).

Today, Canada is one of the most advanced countries in the field of media pedagogy. The media culture in this country is an integral part of education. Media education courses are available at almost all Canadian universities. Almost every Canadian province has its own Media Education Association, which holds scientific and methodological conferences, publishes media products (newspapers, magazines), and prints teaching materials. So, studying the experience of Canadian media theorists and practitioners is necessary for the Ukrainian education system to adequately solve the problems of implementing media education and developing the ways of improvement of the Ukrainian educational system in the context of reforming, humanizing and globalizing the educational space.

In this perspective, it is useful to trace the history of the evolution of media education in Canada. Knowledge of historical development can serve as an advisor in the development of modern concepts for the implementation of media education in the in educational institutions in Ukraine.

\section{Analysis of the Relevant Research and Publications}

Media education aims at using the most of the educational, technical and communicational potential of modern mass media and, as UNESCO defines, it is a separate area of education, since it helps people to understand ways of using mass communication in society; to analyze media texts and critically evaluate the values, political, social, commercial and cultural interests, as well as to create and disseminate their own media texts through mass media [1].

In the definitions of UNESCO [2], media education and media competence are consistently associated with the development of democratic thinking and the development of civic responsibility of an individual. According to the outcome documents of many international forums, such as the Alexandrian Proclamation on Information Literacy and Lifelong Learning [3], which discuss the problems of media education, the media process in the world is based on civil responsibility, humanism and democracy.

Canada is the home country of the famous researchers who contributed to developing media theory - H. Innis, M. McLuhan, R. Morgan, D. Buckingham, and D. Smythe. M. McLuhan was the first who developed in Canada the special course on media culture in the 1950s. Robert Morgan, a cultural studies professor, made a survey among the teachers and characterized problems that emerged while teaching media. The subject of his scientific research was studying how to teach culture and media education theory [4]. Educators Sh. Turkle and D. Buckingham emphasized on the importance of studying the audience who are taught the media theory. They also highlighted the issue of the necessity of implementing media education in the process of teacher training as teachers should deal with the ways students process media. Teachers should decide what the starting points for studying media are $[5,6,7]$.

The interconnection and mutual influence of education, the mass media and culture are presented in the research works of foreign scientists: French scientists J. Gonnet, E. Bevort and L. Porsche, American media theorists J. Lull and J. Peters; the psychological aspects of mass media are dealt with in the papers of the English media expert R. Harris.

American media education is also based on the work of the famous Canadian media theorist M. McLuhan, the British media educators L. Masterman and K. Bazalgette and other English-speaking researchers, as well as on such basic concepts of media education as "category", "agency", "language", "technology", "audience" and "representation" [8]. At the present stage, media education is integrated into the curricula of all 50 states. There are also a number of media education associations in the United States. Among them there are the Media Education Center in Washington DC, the National Council for Television and Media in Virginia, the Media Literacy Center in Los Angeles, and others. Some professional associations of teachers are trying to achieve the inclusion of media education in the state standards [9].

In today's media education practice, American educators widely use the potential of the Internet and television, and focus on the fact that the PBS (Public Broadcasting System) model is one of the examples of 
effective media and education interaction between universities. Note that in the American media education, unlike Canadian one, the most important aspect is successfully realized, i.e. the media education of teachers and future teachers. So, media education in the United States is also at a rather high level.

Summing up, we may state that the ideas of M. McLuhan significantly influenced the development of media education all over the world and as $\mathrm{N}$. Andersen claims that media education theory in Canada is special and unique and it should be studied for further researches [8].

\section{The purpose of the article}

The purpose of this article is to overview key media education movements and organizations within Canada; to identify the main stages of the development of media education in Canada; to present the evolution of media education programs, methodologies, and media education associations; to determine the perspective for developing positive Canadian experience of implementing media education in teacher education in the conditions of globalizing and humanizing the educational space.

The investigated period (since 1940 to present) is full of promising unique programs, significant achievements in the development of educational innovative technologies in distance education, media pedagogy, which are based on respect for human rights, critical thinking, the formation of a well-cultured personality, his information competence and literacy.

\section{Methods}

In the article a set of research methods was used: general scientific methods (analysis, synthesis, comparison, analogy, comparison and contrasting), which allowed to synthesize and systematize the views of Ukrainian and Canadian scientists on the research issue, as well as to justify the original theoretical and methodological points; scientific-historical methods (chronological one, the method of periodization, logical-historical and historical-genetic method) that provided the study of the preconditions for the formation of media education, the elucidation of the stages and leading trends in the development of media education in the practice of the studied period; formalized methods: scientometric analysis, methods of interpretation, systematization, generalization for the disclosure of the features of the development of media education in Canada. Terminological analysis of scientific literature made it possible to define the basic concepts and categories according to the subject of the research. Theoretical generalization, methods of functional-structural analysis were used to formulate the main points and conclusions of the study on the role of media education and the generalization of the experience of overcoming the problems of media education in Canada.

As the criteria for the periodization of the historical development of media education in Canada were chosen: socio-economic, scientific and technical, cultural and educational development of society. In accordance with this, three main periods of development of media education were identified and presented below.

\section{Results}

The logic of our study requires understanding and clarifying the concept of "periodization" and defining it in relation to the historical and pedagogical issues.

As the scientists claimed, periodization should be understood as the logical delineation of the investigated period in accordance with its qualitative characteristic in relation to certain stages. Such a characteristic should reflect both the general laws of development of public life and specific in its content, significant moments of the basic methods and forms of the genesis of the problem and the determining stages of its development.

"Periodization is a basic construction that we use in our imagination, which is based on a strict scientific analysis of the research objects that is a diverse set of sources that forms the preliminary analytical work and finds its expression in the creation of a hypothetical image of the cognitive object. Periodization is a definite scheme (core, skeleton), on which we "collect" a set of events - the results of our cognitive activity in the form of "facts-knowledge", which in their totality represent the image of a certain phenomenon that acts for us as an object periodization - the object of knowledge".

The periodization is considered as the distribution of the whole process of scientific development into segments of time, which differ from each other with specific features established on the basis of objective criteria and principles. This distribution may be general in nature and relate to the whole science or its part, which has certain distinctive characteristics that determine the more detailed allocation of time limits. Therefore, periodization can be structurally represented as follows: era, period, stage. The historical era is not a logical abstraction. In the case of periodization of education history, it should be noted that education history synthesizes a variety of socio-economic, didactic, psychological and pedagogical phenomena and processes. Understanding the historical epoch includes the definition of the leading trends in the development of certain educational phenomena. It should be added that the establishment of certain limits of the historical era cannot be "absolutized", because they are conditional and dynamic. Consequently, the epoch is a more general concept compared with the period. In turn, the period is a more general concept than a stage. The period is the length of time during which a process occurs. The stage is a period of time in the development of any movement or process. The stage acts as part of the period and may differ because it includes the main and the most important events of the period, that is why it carries its essence. However, there may be the stages of a preparatory nature, the completion of what has been done during the main stage, the stages of comfort, and others. We accept such an interpretation of the concepts of "period" and "stage", especially since it coincides with the position of most historians, in particular, historians of education.

Based on the theoretical developments of Canadian media theorists (M. McLuhan, M. Mitchell, 
A. Hodgkinson, G. Moore, C. Worsnop, N. Andersen, B. Duncan, J. Pungente, et al.) and emphasized the following criteria for periodization - socio-economic, scientific and technical, cultural and educational development of society, we consider it appropriate to identify the three main periods of the development of media education in Canada. The first period covers the 1940 s - the beginning of the 1970s (this is the period of the birth and establishment of media education in Canada). The second period is since 1972 to the beginning of the 1990s (the period of development of media education and its integration into the system of secondary and higher education in Canada) and the third period is the 2000s to the present (this is the modern period of media education development) (Table 1).

The first period of the "Birth and development of media education in the Canadian education system" is divided into three stages. The first stage of this period is "Emergence of the foundations of media education in Canada". This is the time when the media education movement in the North American continent was still in its infancy. Its borders cover the 1940s - the beginning of the 1950s.

According to the respectable Canadian scholars such as N. Andersen, B. Duncan, J. Pungente, the emergence of media education in Canada at this stage was caused, first of all, by two main factors $[10,11]$ :

1) intensive expansion of Canadian society by the American "pop culture";

2) flexible and progressive education system that created favourable conditions for the emergence of new educational paradigms.

Table 1 Historical periodization of the development of media education in Canada

\begin{tabular}{|c|c|c|c|}
\hline Period & Stage & Stage Title & Trends and representatives \\
\hline \multirow{3}{*}{ 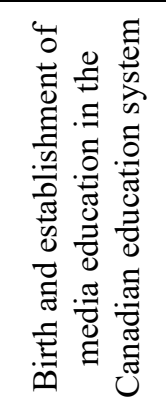 } & $\begin{array}{l}1940 s- \\
1950 s\end{array}$ & $\begin{array}{l}\text { Emergence of the } \\
\text { foundations of media } \\
\text { education in Canada }\end{array}$ & $\begin{array}{l}\text { Marshall McLuhan`s theory was based on the idea that "every media } \\
\text { has its own" technological grammar "and creates a unique message. }\end{array}$ \\
\hline & $\begin{array}{c}1950 \mathrm{~s}- \\
1960 \mathrm{~s} \\
\end{array}$ & $\begin{array}{l}\text { Development of the } \\
\text { media education system }\end{array}$ & $\begin{array}{c}\text { Development of the "Art Concep" in Canadian secondary school and } \\
\text { visual literacy by M. McLuhan. }\end{array}$ \\
\hline & $\begin{array}{l}\text { 1960s - the } \\
\text { beginning } \\
\text { of the } \\
1970 \mathrm{~s}\end{array}$ & $\begin{array}{l}\text { Media education } \\
\text { Integration in Canadian } \\
\text { secondary and higher } \\
\text { education }\end{array}$ & $\begin{array}{c}\text { Domination of the aesthetic theory of media education. Influence of } \\
\text { the ideas of M. Mitchell and A. Hodgkinson. }\end{array}$ \\
\hline \multirow{3}{*}{ 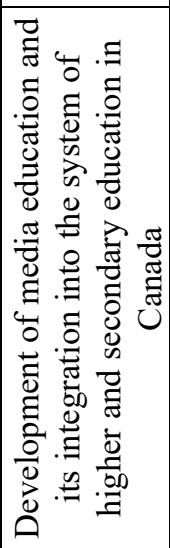 } & $\begin{array}{c}1972- \\
1977\end{array}$ & $\begin{array}{l}\text { Media education } \\
\text { regression in Canada }\end{array}$ & $\begin{array}{c}\text { Principle of 'back to the foundations', media education was } \\
\text { considered as "unnecessary luxury". }\end{array}$ \\
\hline & $\begin{array}{c}1978- \\
1989\end{array}$ & $\begin{array}{c}\text { Renewal of the positive } \\
\text { trends in the development } \\
\text { of media education in the } \\
\text { Canadian education } \\
\text { system }\end{array}$ & $\begin{array}{l}\text { Development of semiotic and cultural theory of media education. The } \\
\text { brightest representatives and theorists of which are C. Wornstop, } \\
\text { J. Pungente and B. Duncan. Foundation of the Jesuit Communication } \\
\text { Project. }\end{array}$ \\
\hline & $\begin{array}{l}1990- \\
1999\end{array}$ & $\begin{array}{l}\text { Sequential integration of } \\
\text { compulsory media } \\
\text { education in the } \\
\text { Canadian education } \\
\text { system }\end{array}$ & $\begin{array}{l}\text { Publication of the textbook on media literacy (B. Duncan). The } \\
\text { outstanding representatives are N. Andersen, J. Pungente. The } \\
\text { establishment of media associations in all provinces of Canada. }\end{array}$ \\
\hline \multirow{2}{*}{ 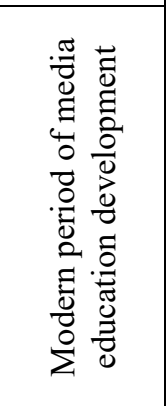 } & $\begin{array}{l}2000 s- \\
2009\end{array}$ & $\begin{array}{l}\text { Education reform, } \\
\text { reflection of the best } \\
\text { practices in media } \\
\text { education in secondary } \\
\text { and higher schools in } \\
\text { Canada }\end{array}$ & $\begin{array}{l}\text { International forums and world conferences on media education were } \\
\text { held in Toronto and Montreal. }\end{array}$ \\
\hline & $\begin{array}{l}2010 \mathrm{~s}- \\
\text { present } \\
\text { times }\end{array}$ & $\begin{array}{l}\text { Modernization, further } \\
\text { improvement of media } \\
\text { education programs and } \\
\text { technologies }\end{array}$ & $\begin{array}{l}\text { Development of modern media literacy and media education } \\
\text { programs. The brightest representatives are C. Wing and C. Wilson. }\end{array}$ \\
\hline
\end{tabular}

The birth of media education in Canada, as in most other countries of the world (the USA, the UK, France, Australia), took place on the basis of cinematographic materials in the 1940s - 1950s. According to the survey, a common Canadian student had spent about 15,000 hours in front of the TV screen before he left school and had watched at least 500 films [12]. Therefore, the rapid development of television and the high intensity of students' contacts with the new audiovisual media forced 
the teachers to reflect on the consequences of this impact.

A well-known Canadian scientist and educator Herbert Marshall McLuhan made a significant contribution to the development of media education at this stage. He emphasized the educators' attention to the growing popularity of the new visual culture in the lives of young people and encouraged for the active use of the rich potential of audiovisual culture for teaching students through non-verbal communication methods. Marshall McLuhan was one of the first educators who used the concept "media" to determine mass media. The scientist claimed that the media have a certain impact on society (in particular, the children's audience). The famous quote by Marshall McLuhan "Medium is a message" quite clearly reflects the scholar's opinion that media texts can be perceived differently. In accordance with this, there was a need for the development of media culture [13].

Thus, the first official mention of the birth of the media education movement in Canada can be attributed to the 1950s, when the concept of screen education was formed by British activists who established Society for Education in Film and Television in 1950. In general, due to the fact that television began to develop intensively in the 1940s and 1950 s, there was a problem of regulation of interaction between students and the media. Canadian educators understood the futility of attempts to shield students from the ever-increasing influence of television and cinema, and they understood the need to develop and implement special courses and programs to help students adapt better in the media world as well as optimize the learning process itself.

The second stage "Development of the media education system" is characterized by the emergence of basic concepts of media education in Canada, which has now grown into an international educational movement that began in the second half of the 1950s. The media education theorist and teacher M. McLuhan proposed the concept of "Global village", which laid the ground for the dialogue of cultures in the information society of the era of globalization. "Globalization" and "Information Society" are two complementary phenomena that determine the nature of the modern era [8].

Canadian educators are increasingly concerned about the rapidly spreading and ever-increasing impact of the media on the lives of the young generation. Leading scholars recognized the existence of competition between school and the media, which was identified as a "parallel school". However, at that time, no constructive decisions about the need to include the "media education" course in schools or higher education institutions were not adopted. In 1959, M. McLuhan developed a curriculum for the 11th form of secondary schools for media education (Toronto), which undoubtedly became the basis for the further development of media education programs and courses for both the secondary and higher education in Canada [8].

The third stage entitled "Media education integration in Canadian secondary and higher education" is known as the stage of "Screen Education". The rapid development of communication and information technology in the second half of the twentieth century led to the fact that the original term "Film Teaching" as the study of cinema that reflected the narrower orientation of the course transformed into the term "Screen Education".

In 1965, the Toronto Ministry of Education initiated a one-day conference on cinema education, which in those years became very popular among educators and civil activists. In 1968, the Ontario Ministry of Education provided the position of assistant coordinating work in the field of "Screen Education", which led to three similar one-day conferences, each of them numbered about 200 participants. The main achievement of these conferences at this stage was the creation of an information committee, which eventually became a harbinger of the future media education association. Approximately at the same time, student film festivals and conferences devoted to media education were actively held around the world. So in 1968, the first international conference "International Conference on Communication Media Education" took place under the patronage of British professor A. Hodkinson. The conference addressed the issues of media education in different countries and analyzed the national experience of various countries, such as the United States, Britain, Australia and Canada. Also in the same year in Halifax (Nova Scotia province), the first student film festival took place, where young participants from Canada, the USA, Italy, Great Britain, Australia and other countries of the world demonstrated their achievements. Immediately after the festival in Ontario, the School Council even initiated a space for films created by Canadian students.

In 1969, thanks to the enthusiasm of a creative group and an information committee that disseminated the idea of the need to create an official media education structure, it was founded the Canadian Association for Screen Education (CASE) [10]. Already in June 1969, at the York University in Toronto, thanks to the efforts of this association, the first conference was held throughout the country. The result of the event was a course with the introduction of the aesthetic theory of media education. After all, "the purpose of aesthetic education is to teach the younger generation to think critically... to learn to see the difference between good and bad films and TV shows" [14].

A significant support from the National Film Board (NFB) for providing a resource base for "Screen Education" had also positively influenced the introduction of media education in the Canadian education system. In the period of 1960 s -1970 s, about 40 representatives of the National Film Board functioned on the territory of Canada.

The "Screen Education" course was available at a number of Canadian universities, for example, at Loyola College, McGill University and Sir George Williams University.

However, despite all the positive changes in implementing media education in the educational process, the second period "Development of media education and its integration into the system of higher 
and secondary education in Canada" began with the stage of media education regression. Analysing the process of development of "Screen Education" in the 1960s, we identified a number of problems that complicated the work of teachers on the introduction of "Screen Education" in the educational process of the educational institutions in Canada. The overload of curricula that did not allow for the inclusion of a course in the schedule, orientation of the majority of teachers and official representatives of the educational institutions in the print media, the lack of proper funding of media education programs for a centralized information resource, and the lack of common standards for the development of media culture hampered the process of developing and implementing media education in the Canadian education system.

Mostly only in Ontario, media education projects were implemented. In the 1970s, the course for implementing media literacy was called "unnecessary luxury" [15].

But even in rather difficult socio-economic conditions, at the regression stage, media education was carried out at the expense of individual educatorsenthusiasts who tried to integrate the "media education" course in a school curriculum based on the cinematic material, television and press.

However, in 1978, the second largest association the Association for Media Literacy (AML) - was founded in the country in order to support media educators that created favorable conditions for the further development of media education at the next stage, entitled "Restoration of the positive trends in the development of media education in the Canadian education system".

At the end of the 1980s, media education improved significantly. An example of such improvement was the emergence of a significant number of regional associations in the field of media education. In January 1988, a guiding conference made a decision to create the Media Literacy Association in Saskatchewan (MLS). Mike Ellis (the first Canadian who received the degree of media education at London University, England), and other teachers in Saskatoon created the Media Literacy Saskatchewan. The aim was to identify and communicate between teachers, support the development and integration of media literacy in the educational curriculum, to influence education policy, to provide professional support, to maintain contact with Canadian and international organizations. The members of the Media Literacy Saskatchewan developed three programs - "TV media", "News media" and "Children's Media" for use in schools, the written part of the program for studying film and literature for the senior English course and published the "Handbook of media literacy from primary to high school". This course included the subjects that were integrated with all aspects of the curriculum for primary and secondary levels. The Saskatchewan media literacy organization published a quarterly bulletin "Media View", which included practical information, bibliography, review of books and audiovisual resources, and the development of lessons. Saskatchewan had six categories of collaborative research that were integrated into all courses of study. Two of them - "Communication Skills" and "Critical and Creative Considerations". Using these two studies, the MLS developed the proposals how to integrate media education throughout the primary and secondary curriculum. Media literacy proposals consisted of such key concepts as text, audience, representation, and products. Saskatchewan arts policy required media literacy, which in the future would integrated into the curriculum not only as part of basic education, but also as a support for the foundations of the language art. Even so, several schools in Saskatchewan offered such courses because there were no trainings for teachers in this field. After all, the MLS worked for the interest of schools and provided them with programs for improving their teachers' qualifications.

The Jesuit Communication Project (JCP) that was formed in 1985 in Toronto had a great impact on the development of media education in the country. Since 1985, the TV channel CHUMTelevision also actively supported the development of media literacy. It was a channel (the first in the world) that introduced a special department on media education. In 1999, the leaders of CHUMTelevision were invited by the UNESCO World Organization to participate in a conference on the exchange of experiences.

In 1989, the first Media Literacy Resource Guide was published with the support of the Ontario Ministry of Education and the Media Literacy Association (AML). The main purpose of the textbook was to help teachers use their media potential [16]. The publication of the first textbook on media education in some way became the basis for the introduction of this course into the curriculum of Canadian educational institutions.

Generally, the development of Canadian media education since the 1980 s was very productive. Provincial organizations throughout the country organized conferences, developed curricula and programs, held workshops and trainings, lectures on various aspects of media education.

Only in 1973, UNESCO proposed that the media should be studied through higher and secondary education curricula. And in 1977, UNESCO announced media education as a priority area for the coming decade.

It should be noted that the Federal Ministry of Education did not exist at the national level in the country. Unlike other developed countries, Canada does not have a nationwide system of education: according to the constitution and administrative structure, each of ten provinces and three territories has its own educational structures. This provision makes it difficult to meet the uniform requirements for provincial educational institutions. At the same time, this country has been the world's leading one in the field of media education for more than twenty-five years. In Canada, the study of media culture became an integral part of the school curriculum for all secondary school students in September 1999.

The third stage of this period is "Sequential integration of compulsory media education in the Canadian education system". The constantly growing role of the media in the life of modern society led to the 
rapid development of information technology and computer technology in the 1990s. It inspired a new impetus for the development of media education in Canada. There was a need for purposeful integration of media education into the educational process.

The intensive development of modern information and telecommunication technologies contributed to the formation of new approaches to education. In the 1990s, the computerization of schools was intensively taking place in all provinces of Canada. In 1999, the first part of the Schoolnet program was started. It connected 16,000 Canadian schools and public libraries to the Internet. We draw attention to the fact that the last school that joined the Schoolnet program was a school on the island of Pictou (Nova Scotia province), where only three students studied. So today, the Schoolnet is a unique educational resource (more than 7,000 teaching materials) for Canadian educators. Schoolnet also acts as a virtual educational center for both educators and students who are trying to master the skills of using the computer and the Internet.

It the 1990s, the new educational standards appeared that included the mandatory introduction of media education in the curriculum of school programs. Since 1993, departments of education in the British Columbia, Alberta, Manitoba, Saskatchewan, Yukon, Nunavut and Northern Territories have been actively collaborating within the framework of the Western Canadian Protocol for Collaboration in Basic Education (WCP). Due to this cooperation, at this stage, the specialized methodological centers were created to develop the unified theoretical foundations of curricula that included the media education course. Since 1997, the representatives of provincial departments of education have started developing their own programs and implementing relevant documents that provide the teachers with the necessary pedagogical strategies in the field of media education.

The official documents of the Western Canadian Protocol on Cooperation in Basic Education highlighted the relevance of the media education course: "Understanding the meaning of verbal and other forms of media texts is important for living in democracy. Thus, by studying various media texts, students have the opportunity to gain a wealth of experience, to learn other cultures. In the process of working with media texts, students analyze, synthesize, evaluate and create their own media products" [9].

In the east of the country, a similar organization operated, it was the Atlantic Provincial Education Foundation (APEF), which included Nova Scotia, Labrador, Newfoundland, New Brunswick, and Prince Edward Island. In 1995, the eastern provinces declared their desire to integrate the media education elements into the program "English Language and Arts". In 1996, the curriculum was successfully tested, and since 1997, its implementation has started. The successful integration of this program into the "English language and Art" course is due to the fact that the concept of literacy in the 1990s went beyond the scope of written language and has included the ability to use and understand the visual and technological means of communication. Consequently, according to the abovementioned documents, at the end of the twentieth century, media education became an important part of the English language and art training course, as well as a real media education reform through the Atlantic Provincial Education Fund and the Western Canada Canadian Cooperation in Basic Education in Canadian Provinces.

The Ministries of Education in Quebec and Ontario were not part of these organizations, but had similar functions for the implementation of the media education initiatives in the educational process of their provinces.

Ontario was the first province where media education became a compulsory part of the curriculum. The Ontario Media Education course consisted of verbal and visual communication, with emphasis on the need for further knowledge, skills and competences: the classification of media genres and the selection of media elements related to it. In April 1995, the Ontario Ministry of Education approved two formal documents: "Curriculum: Concept and Learning Outcomes from Grades 1 to 9" and "Ontario Provincial Standards: Language and Literature, Grades 1-9”. The first document clearly identified the amount of knowledge and skills that students should receive, the other document provided objective and logical indicators to determine the success of student learning. A compulsory course in English and Literature from grades 1 to 9 should include listening and speaking, reading, writing, reviewing and presenting.

The regulations of Ontario province set the new standards for education and emphasized the need to introduce media education as part of a traditional curriculum of native language and literature. According to these standards, one third of the English language in middle and upper grades of the school should be devoted to the study of the media. In the seventh and eighth grades, at least 10 percent of the time of education should be allocated to the study of media education. In addition, students were given the opportunity to independently choose an autonomous media course one of five special courses - within the framework of the English language curriculum [10].

Since 1993, the New Technologies of Montreal University have successfully conducted the large-scale experiments in the field of media education. The results of these fundamental experiments contributed to the adoption of strategic decisions in the field of the media industry. While working on the project "Children and Media" under the supervision of A. Caron, the problems of contemporary media education were studied: they analyzed the television preferences of Canadian children, the family perception of television broadcasts, stereotypes and violence on the screen, the educational potential of television and interactive technology for children, regulation of advertising in children's programs, social advertising and promotion of a healthy lifestyle [17]. The main purpose of these studies was to obtain reliable data for the objective assessment of the perception of the media space for the children's audience. 
The rather complex nature of the Canadian education system certainly influenced the peculiarities of the development of the media education process in the country, but in turn, it allowed each province to carry out media education reforms independently. A characteristic feature of Canadian media education, which cannot be ignored, is the presence of many associations that operate in every province of the country. First of all, at this stage, the following media educational associations were formed:

1. Manitoba Association of Media Literacy (MAML) was founded in October 1990, thanks to the results of the conference "Special Areas Group" (SAG), funded by the Association of Teachers of the Humanities. At that time, several representatives interested in media education met with members of the Ontario Media Literacy Association Neil Andersen and John Pungente. The result of this meeting was the formation of MAML. The purpose of MAML is to promote the goals of media education and to help investigate the role of media in society. MAML enables to provide the following opportunities: to develop the skills, knowledge, attitudes needed to explain the media, develop social, cultural, political and economic consciousness, develop an evaluation and aesthetic understanding of the media. To accomplish these goals, MAML sponsors conduct workshops for teachers, parents, participate in the development of media literacy programs for schools, provide opportunities for teachers to improve their qualifications, and publish manuals and quarterly bulletins. The Canadian province of Manitoba has an official regional media education policy. Teachers of the Humanities research the media as a part of their English-language course. In 1992, Manitoba University offered the summer media education courses for teachers to improve their knowledge.

2. The Association for Media Education in Quebec (AMEQ) appeared in September 1990 with an initiative group of teachers of English and French-language secondary school teachers, university professors got interested in media literacy, so they met at the Protestant School in Montreal to create the Media Education Association. French researchers J. Gonnet and R. La Borderi had a significant impact on the development of media education in Quebec [18]. At the end of the 1990s, the Quebec Ministry of Education reformed the curriculum of junior and secondary education and implemented a multidisciplinary approach to the integration of media education. In connection with the new school reform aimed at modernizing the entire provincial education system, teaching media education is incorporated into the curriculum of most major disciplines and is one of the leading areas of education. AMEQ also sponsors various student media festivals, media literacy conferences, workshops for teachers and parents. The association representatives regularly report to the Quebec Ministry of Education according to the curriculum changes, as well as to the Canada Telecommunication Commission for Radio and Television.

3. The Canadian Association for Media Education in Vancouver (CAME) and the British Columbia
Association for Media Education were founded in 1991 (BCAME). In 1994, the associations organized summer courses for teachers and began to publish training manuals and recommendations for media educators. In the same year, the associations attracted the Ministry of Education by their projects. This led to the fact that in autumn 1996, British Columbia became the first province to introduce the compulsory study of the media into the educational process (the courses in Art and English);

4. The Association for Media Literacy in Nova Scotia (AML-NS) was founded in 1992. The first original objective of the association was to provide information, lesson plans, knowledge and experience, professional development of teachers', pupils' and parents' media literacy.

5. The Canadian Association for Media Education Organizations (CAMEO) was established in 1992. The purpose of the association wass to coordinate the efforts of media educators from different provinces.

6. The Alberta Association for Media Awareness (AAMA) appeared in the spring of 1993. A group of teachers and media professionals organized this association. The purpose of the work was to promote the media consciousness of education and understanding, to provide information support, to organize forums for information, discussions, publishing activities, preparing conferences and trainings for teachers, and to support the resource centre.

The main strategic goal of all the above-mentioned associations was to promote the development and integration of media education among children, adolescents, and adult audiences.

Thus, since 1999, the study of the media culture course throughout the country has become an integral part of the school curriculum of secondary education institutions. Between 1989 and 2004, the most provincial departments and ministries of education gradually introduced media education to the courses in the arts and the English language at higher educational institutions.

The third period "Modern period of media education development" consists of two stages "Education reform, reflection of the best practices in media education in secondary schools and higher educational institutions in Canada" and "Modernization, further improvement of media education programs and technologies".

During this period, UNESCO has been actively involved in developing the foundations for media and information literacy and has supported UNESCO Member States, including Canada, for achieving the goals set out in the Grunwald Declaration on Media Education (1982), the Alexandrian Declaration on Information Literacy and Education Throughout Life (2005) and the Paris Summit of UNESCO (2007).

Let's consider the first stage of the third period "Education reform, reflection of the best practices in media education in secondary schools and higher educational institutions in Canada". With the growing demands for education reform (new types of literacy, updating of educational technology and communication, creation of larger educational institutions), the renewal of the teacher's role in the educational process becomes 
important. The teachers of the new educational structure should not only fulfil their basic responsibilities: mentoring and management of the educational process, the transfer of values and social guidance, monitoring the conditions due to which the learning process and educational communication take place, assessment of progress, and the process of managing the strategy. But the future teacher must master additional competencies:

- ability to model contexts, situations and circumstances for the educational process by using the potential of information and communication technologies;

ability to upgrade, adapt, obtain and develop educational materials based on a multimedia basis; ability to organize effective communication of the school community with the use of information and communication tools and the involvement of new media; ability to work with information and communication technologies;

- $\quad$ ability to create virtual co-operative networks;

- $\quad$ ability to realize the psychological impact of new media on students;

ability to adapt to new relationships related to the sharing of duties, abilities and energy that are created on the basis of educational activities as a result of the transformation and the advanced education system.

The key event in Canadian media space during this stage was the worldwide largest scientific and methodological conference "Summit 2000: Children, Youth and the Media - Beyond the Millennium", held in Toronto in 2000. The conference was attended by more than 1500 representatives from 54 countries of the world. The sponsors of the event were the leading television organizations and companies related to the media and education. The main goals of the conference were to support the effective media education of the children, youth and adult audiences, stimulate the dissemination of the best educational programs and practical methods, converge the views of media workers (producers, film and television script writers) and media education (teachers and university lecturers). Such events enable the development of cooperation between media professionals from different countries, scientific schools and technological approaches.

At the beginning of the XXIst century, two media educational associations were created. The Media Literacy Association in New Brunswick (AMLNB) was founded in 2001, and the Association for Media Literacy in Newfoundland and Labrador Media (AML-NL) in 2002. The purpose was to develop the media education system in their own provinces.

The major event for Canadian media education became the Canadian National Week of Media Literacy in 2006, with the support of the Media Awareness Network and Media Smarts and the Canadian Teachers' Federation. The main goal of the current event is to encourage teachers and students in the field of media education and support the integration of media education into curricula and programs. Now, for the twelfth year, the Week of Media Literacy is being held, which has become not only a Canadian, but also an international event in the life of media educators.
"The Understanding of Media Literacy: Inside Plato's Cave" course has been integrated since 2009 into the curriculum of Atbauche Unversity (Alberta, Canada). This course includes introducing media literacy, examples of media education programs from leading Canadian universities and core modules.

The stage "Modernization, further improvement of media education programs and technologies" had a great event for the development of media education in Canada. It was the organization "Generation of Young Canadians in the World of Internet. Phase III: Online Life" in 2014. The program focuses on the attitude of the younger generation to the global Internet network, and aims at exploring what young people are "doing online", which sites are actively using, their attitude to "online security", home rules for using the Internet, and the disconnection of electronic technologies. On the site of the presented program Media Information Network has published a large number of sources on media literacy on a variety of topics: from a gender image in the media space to "cyber bullying", marketing and consumer protection for parents, teachers and students in both the official languages (English and French).

\section{Conclusions}

The experience of famous Canadian media educators provides grounds for arguing that the media plays a crucial role in the Canadian education system (especially in the educational process in secondary schools and higher educational institutions).

The research that we have conducted with regard to the historical periodization of the development of media education in Canada, based on the following criteria for periodization, such as socio-economic, scientific and technical, cultural and educational development of society, allow us to distinguish three main periods. The first period covers three stages (the 1940s - the beginning of the 1970s (this is the period of the birth and establishment of media education in the Canadian education system). The second period, which also encompasses three stages, is 1972 - the beginning of the 1990s. This is the period of the media education development and its integration into the system of secondary and higher education in Canada and the third one is the $2000 \mathrm{~s}$ - up to date. This is the modern period of the media education development, which includes two stages.

In 1959, a famous Canadian researcher created the first media education program for 11th grade students and included it into a school curriculum. It was Marshall McLuhan. In the early 1960s, the system of high quality specialists for the film and cinema education was still in the stage of formation. Nevertheless, the part-time evening courses that trained instructors for screen culture were organized on the basis of colleges and universities. The peak of media education in Canada was in the end of the 1980s, which led to the establishment of media education associations in all provinces, but media education was not compulsory in the school curriculum due to the lack of a unified state centralized education system. However, today the Canadian media literacy network has become well-known around the world 
thanks to the active work of the media education associations that operate throughout the country and produce educational films, publish professional journals, and offer seminars, training programs, manuals, etc. As a result of the theoretical analysis of the determined periods, we have characterized the process of establishment and development of media education in the Canadian education system. Consequently, the Canadian media education received its modern status in the process of evolution, and the established methodological and theoretical basis contributed to the consistent transition from optional to compulsory study of the media education foundations in Canadian educational institutions. And now Canada is a recognized media education leader in the world.

However, our study does not cover the problems of media education as a scientific, historical and educational phenomenon, as the study of theory and practical skills for mastering modern mass media, that are considered as part of a specific, autonomous field of knowledge in education theory and practice. To the directions of further explorations, we include a review of foreign experiments in the field of media education; an analysis of the works by Western educators on the ways of implementing media education and the achievement of media literacy; the search for common ways with other countries in the training of specialists in the field of media education; studying and implementing the experience of the media education organizations for improving media culture.

\section{References}

1. W. J. Potter, Media Literacy. Thousand Oaks (Sage Publication, London, 2001)

2. Literacy: A UNESCO Perspective (2003), http://unesdoc.unesco.org/images/0013/001318/131 817eo.pdf. Accessed 14 Jul 2019

3. S.D. Garner (ed.), High-Level Colloquium on Information Literacy and Lifelong Learning (2006), https://www.ifla.org/files/assets/wsis/Documents/hig h-level-colloquium.pdf. Accessed 21 Mar 2019

4. R. Morgan, in Teaching the Media: International Perspective, ed. by A. Hart. (Lawrence Erlbaum Associates, New Jersey, 1998), pp. 145-167

5. Sh. Turkle, Life Behind the Screen: Identity in the Age of the Internet (Simon \& Schuster, London, 1995)

6. D. Buckingham, Watching Media Learning (Falmer Press - Gage, Canada, 1990)

7. D. Buckingham, Child. Geogr. 5(1-2), 43-54 (2007)

8. M. McLuhan, Understanding Media: Intentions of Man (McGraw-Hill, New York, 1964)

9. K. Tyner, J. of Med. Lit. 1 (146), 4 (2000)

10. N. Andersen, in: Children and Media: Image. Education. Participation, ed. by C. von Feilitzen, U. Carlsson (1999), pp. 139-162

11. B. Duncan, Media Literacy Resource Guide. Ontario Ministry of Education and the Association for Media Literacy (Queen's Printer for Ontario, Toronto, 1989)

12. G.J. Moore, The Case for Screen Education in Canadian Schools (Canadian Education Association, Toronto, 1969)

13. M. McLuhan, The Mechanical Bride: Folklore of Industrial Man (Vanguard Press, New York, 1951)

14. F.K. Stewart, J. Nuttall, Screen Education in Canadian Schools (Canadian Education Association, Toronto, 1969)

15. K. Uing, What is the Internet literacy? The handbook on the freedom of mass information on the Internet (Wien, 2004)

16. Media literacy resource guide, intermediate and senior divisions (Ministry of Education, Ontario, 1989)

17. A. Caron, Centre for Youth and Media Studies (Montreal, 1998)

18. J. Gonnet, Education aux medias: Les Controversies fecondes (CNDP, Hachette, Paris, 2001) 